\title{
Influence of mechanochemical treatment on thermal and structural properties of silica-collagen and hydroxyapatite-collagen composites
}

\author{
Barbara Charmas $^{1}$ [D J Jadwiga Skubiszewska-Zięba ${ }^{1} \cdot$ Karolina Kucio $^{1} \cdot$ Ewa Skwarek $^{1}$
}

Received: 29 October 2018 / Revised: 22 January 2019 / Accepted: 2 March 2019 / Published online: 8 March 2019

(c) The Author(s) 2019

\begin{abstract}
The paper presents the results of research on a series of composite materials based on hydroxyapatite, silica gel and collagen as biologically active substances. Their preparation was made using mechanical energy in accordance with the principles of "green chemistry". Mechanochemical treatment was conducted in a planetary mill with different rotations of milling (200 and $400 \mathrm{rpm}$ ) and various periods of time (30,60 and $120 \mathrm{~min}$ ). Temperature and pressure changes generated during the mechanochemical treatment were recorded. The obtained composites were analyzed using the low-temperature nitrogen adsorption/desorption method and thermal analysis (TG/DTA). Very interesting and promising results were obtained encouraging further research in this area.
\end{abstract}

Keywords Mechanochemistry $\cdot$ Green chemistry $\cdot$ Collagen $\cdot$ Silica gel $\cdot$ Hydroxyapatite $\cdot$ Materials porosity $\cdot$ Thermogravimetry

\section{Introduction}

Development of nanomaterials with advanced functional properties is a difficult task due to the growing demand on the market for this type of materials, biodegradable plastics and composites. An example of such functional materials are hydroxyapatite/collagen composites. Such fibers play an important role in the bone tissue engineering. They have an enormous potential as biomaterials because of their accessibility, biocompatibility, ability to combine with other materials, ease of processing, assimilation in the

Electronic supplementary material The online version of this article (https://doi.org/10.1007/s10450-019-00051-3) contains supplementary material, which is available to authorized users.

Barbara Charmas

barbara.charmas@poczta.umcs.lublin.pl

Jadwiga Skubiszewska-Zięba

jskubisz@o2.pl

Karolina Kucio

karolina.kucio@poczta.umcs.lublin.pl

Ewa Skwarek

ewunias@hektor.umcs.lublin.pl

1 Faculty of Chemistry, Maria Curie-Skłodowska University, Maria Curie-Skłodowska Sq. 3, 20-031 Lublin, Poland body and additionally, adequate porosity that potentially facilitates growth of tissues which guarantees a proper connection between tissues in the human organism. The bone tissue is composed of $\sim 70 \% \mathrm{w} / \mathrm{w}$ of mineral part (mainly hydroxyapatite) and $\sim 30 \% \mathrm{w} / \mathrm{w}$ of other components (mainly collagen). The proportion of the constituents differs because of many parameters, e.g. age, health, physical condition and others. In tissue engineering there is a wide range of proposals for obtaining such collagen and hydroxyapatite based scaffolds (Parenteau-Bareil at al. 2010; Sionkowska and Kozłowska 2010; Swetha et al. 2010; Venugopal et al. 2008; Wahl and Czernuszka 2006; Zhou and Lee 2011; Yoshikawa et al. 2008), as well as with other additives such as metals, silica, titania, fibers (carbon, glass, polymers) and others (Harrison and Atala 2007; Aryal et al. 2006; Dorner-Reisel et al. 2004; Sobczak and Kowalski 2007). The applied additives make a significant contribution to the properties of the newly prepared composite. Therefore, the important issue is the choice of a proper additive and type of method.

One of the methods applied in accordance with the principles of "green chemistry" is mechanochemistry. It is a branch of science concerning chemical and physicochemical changes of solids according to different possible mechanisms (Baláž 2008; Baláž et al. 2013; Butyagin 1971) in all physical states resulting from the action of mechanical energy. The conventional way of introducing 
energy into the reaction system is very often associated with long periods of time to achieve the required conditions and high energy consumption. It should be also stressed that the principles of "green chemistry" are the guidelines for reducing the consumption of raw materials, energy, generated wastes and, in general, production costs. The idea is to eliminate processes that generate environmentally harmful organic substances, and also to save reagents and energy. This approach opens the way to the development of modern technologies that are environmentally friendly. Therefore, the issues related to the use of alternative energy sources, including mechanical energy, are the subject of research by many authors (Balaz 2008; Boldyrev 2006; Boldyrev and Tkacova 2000; Sepelak and Becker 2012; Skubiszewska-Zięba 2011; Takacs 2014).

The attempts made at mechanochemical preparation of synthetic hydroxyapatite are known from the literature reports (Chaikina et al. 2014; Fahami et al. 2011; Yeong et al. 2001; Mochales et al. 2004; Pal et al. 2017). A new issue is creating a composite with a structure consistent with the bone tissue, thus containing both hydroxyapatite and the collagen layer. Hydroxyapatite (HAp) belongs to the group of calcium phosphates with the chemical formula $\mathrm{Ca}_{10}\left(\mathrm{PO}_{4}\right)_{6}(\mathrm{OH})_{2}$ (Liu et al. 2003; Skwarek et al. 2014). Taking into account its origin it can be mineralogical, biological and synthetic. The mineralogical HAp occurs in volcanic, metamorphic and sedimentary rocks. Synthetic HAp belongs to the group of calcium phosphates that contain hydroxyl groups, and the $\mathrm{Ca} / \mathrm{P}$ ratio is 1.67 . In bone surgery, HAp is most commonly applied in the form of (a) a porous material, (b) a suitable layer placed on various substrates or as (c) a component of a composite material (Joschek et al. 2000; Sobczak and Kowalski 2007; Swetha et al. 2010).

Collagen is a protein composed of only amino acids. It belongs to the group of fibrillar proteins (scleroproteins). Collagen has many characteristic properties and one of them is the same amount of acidic and basic amino acids. It occurs in many tissues and organs, i.e. skin, bone tissue, muscle, teeth, large blood vessels and the cornea of the eye. Collagen makes up about one-third of the proteins found in the body (Hulmes 2008; Bella et al. 1995).

The paper presents the investigations on (i) obtaining composites based on hydroxyapatite or silica gel and collagen (biologically active substance), using an alternative energy source, which is mechanochemical treatment in a planetary mill as well as (ii) making thorough physicochemical and thermal characterization of the obtained composites. Due to the desired similarity of the composites to biological systems, the components ratio $(70 / 30 \mathrm{w} / \mathrm{w})$ was applied. The adopted mechanochemical procedure allowed to obtain biocomposites without the use of solvents and under appropriate pressure and temperature conditions to protect against protein denaturation. The obtained composites were analyzed using the low-temperature nitrogen adsorption/desorption and thermal analysis (TG/DTA).

\section{Experimental}

\subsection{Materials}

Hydroxyapatite (HAp) for testing was obtained by the wet method according to the following reaction employing the procedure described in the papers (Liu et al. 2003; Skwarek et al. 2014).

$10 \mathrm{Ca}(\mathrm{OH})_{2}+6 \mathrm{H}_{3} \mathrm{PO}_{4} \rightarrow \mathrm{Ca}_{10}\left(\mathrm{PO}_{4}\right)_{6}(\mathrm{OH})_{2}+18 \mathrm{H}_{2} \mathrm{O}$

The bone collagen was in the form of a hydrolyzate (P.P.H. "STANDARD", Lublin, Poland). Silica gel (grain size $\sim 50 \mu \mathrm{m}$ ) came from Degussa, Germany.

The mechanochemical treatment (MChT, planetary mill Pulverisette 7, Fritsch, Germany) was conducted for individual substances, i.e. $\mathrm{SiO}_{2}$ and $\mathrm{HAp}$ as well as with the addition of collagen as a biologically active substance. The details of the grinding procedure are included in Electronic Supplementary Material (ESM). During the milling the generated pressure and temperature values were recorded using the software EASY GTM (Fritsch, Germany). The samples without collagen were designated as $\mathrm{SiO}_{2}-200 / 400-30 / 60 / 120$ for the silica gel and HAp-200/400-30/60/120 for the hydroxyapatite samples. However, the samples with collagen were marked as $\mathrm{SiO}_{2}$-Coll-200/400-30/60/120 and HApColl-200/400-30/60/120. 200/400 corresponds to the rotation speed of the mill, 30/60/120 indicates the grinding time.

\section{Testing methods}

\subsection{Nitrogen adsorption}

The low-temperature (77.4 K) nitrogen adsorption-desorption isotherms were recorded using a Micromeritics ASAP $2405 \mathrm{~N}$ (USA) adsorption analyzer. The specific surface area $\mathrm{S}_{\mathrm{BET}}$ was calculated using the standard BET equation at $\mathrm{p} / \mathrm{p}_{0}$ between 0.06 and 0.2 , where $\mathrm{p}$ and $\mathrm{p}_{0}$ denote the equilibrium and saturation pressures of nitrogen, respectively but $S_{\text {micro }}$ was calculated using the t-plot method (Gregg and Sing 1982). The sorption pore volume $\mathrm{V}_{\mathrm{p}}$ was estimated at $\mathrm{p} / \mathrm{p}_{0} \approx 0.98$ converting the volume of adsorbed gas nitrogen to that of fluid. The average pore diameter $\left(D_{p}\right)$ was calculated for the model of cylindrical pores, $\mathrm{D}_{\mathrm{p}}=4 \mathrm{~V}_{\mathrm{p}} / \mathrm{S}_{\mathrm{BET}}$. Pore volume distributions $\left(\mathrm{PSD}_{\mathrm{BJH}}\right)$ in the function of their sizes were calculated using the Barrett-Joyner-Halenda (BJH) method (Barret et al. 
1951). For comparison, the $\mathrm{PSD}_{\mathrm{DFT}}$ dependences were determined also using the DFT method (Evans et al. 1986; Landers et al. 2013).

\subsection{Thermal analysis}

The thermal studies of the samples were carried out by heating in air atmosphere from 20 to $1000{ }^{\circ} \mathrm{C}$ (heating rate $10 \mathrm{deg} \mathrm{min}^{-1}$ ) using a Derivatograph $\mathrm{C}$ (Paulik, Paulik and Erdey, MOM, Budapest). The TG/DTG/DTA curves were registered. The weight of the test samples was $\sim 20 \mathrm{mg}$. Ceramic crucibles were used.

\subsection{Determination of bulk density}

The bulk density was determined using the classical method of filling the cylinder with a given weight of the material being tested. The measurements details are included in the ESM.

\subsection{Scanning electron microscopy}

The morphology and structure of the silica aggregates were analyzed using SEM with a DualBeam Quanta 3D FEG FEI apparatus under low vacuum conditions at the accelerating voltage of $20.00 \mathrm{kV}$ and magnification $\times 25,000$. The samples were fixed to the aluminum tables with a diameter of $10 \mathrm{~mm}$ and covered with the adhesive carbon film.

\section{Results and discussion}

\subsection{Pressure and temperature effects}

The changes of the pressure and temperature created during the mechanochemical milling depending on the speed of mill and time of MChT are presented in Figs. 1 and 2. From the analysis of the course of the pressure curves versus time (Fig. 1), one can see that for the individual substances $\mathrm{SiO}_{2}$ and HAp (Fig. 1a, b) at $200 \mathrm{rpm}$ the pressure increases initially and with time prolongation up to $120 \mathrm{~min}$ it is minimized to a small extent. However, at $400 \mathrm{rpm}$ this effect is greater, up to $30 \mathrm{~min}$ the pressure rises evidently and with the time prolongation up to 120 min successive pressure drop is observed. Thus, it can be assumed that in the mechanochemically processed material with the increasing time, due to the energy creation, some structural changes take place and a more stable system is formed. While for the samples with collagen (Fig. 1a, b) the observed pressure changes are significantly different. At $200 \mathrm{rpm}$ the pressure increases at the beginning and with the extension of MChT time for the HAp+Collagen systems, the pressure decreases only to a small extent. However, for the $\mathrm{SiO}_{2}+$ Collagen systems, a significant pressure drop can be observed along with the treatment time. The interesting fact is the observed increase in the pressure and then its significant decrease in the samples with collagen treated mechanochemically at $400 \mathrm{rpm}$. Particularly noteworthy is the curve for HAp+Collagen (Fig. 1b) which, with an extension of time
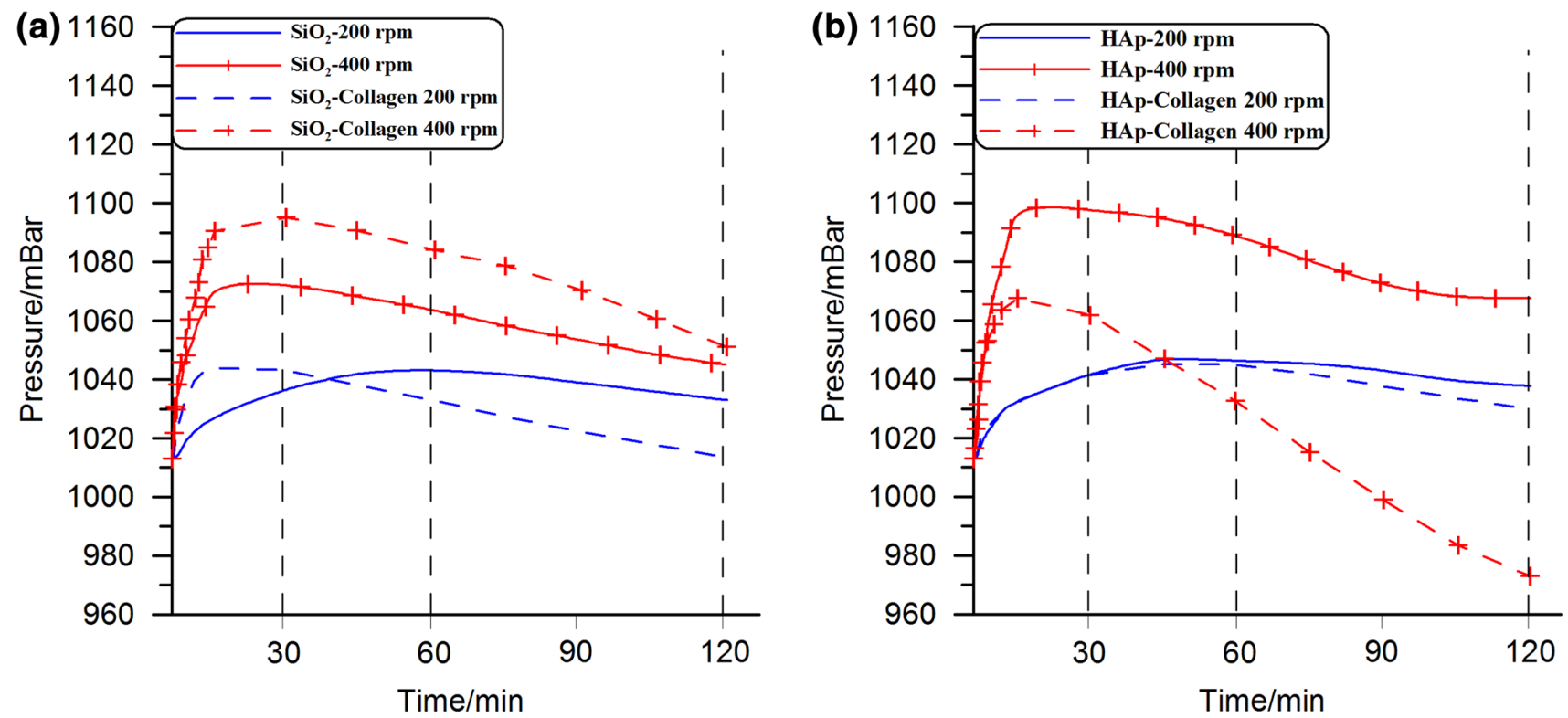

Fig. 1 Values of pressure created during the MChT processes depending on time 

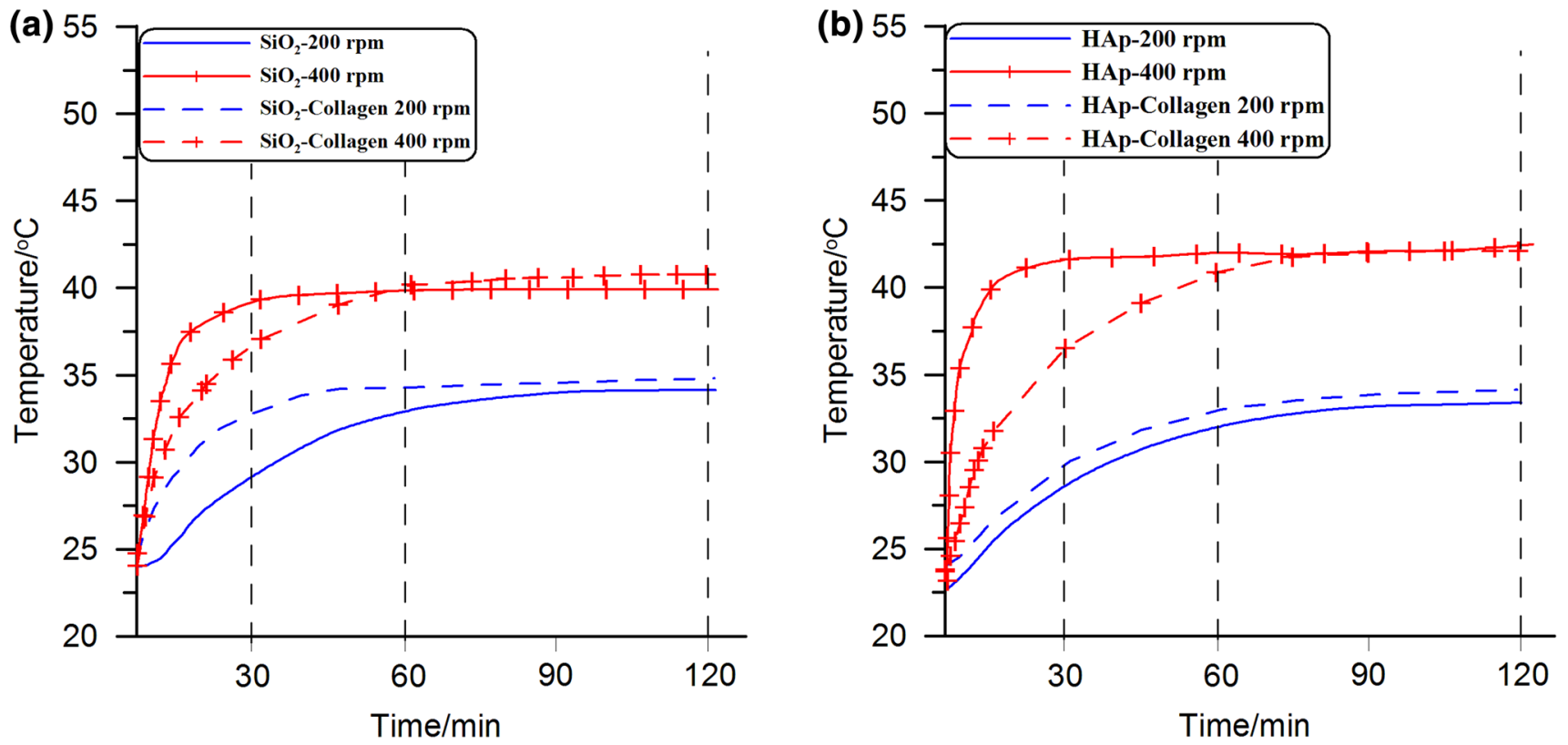

Fig. 2 Values of temperature created during the MChT processes depending on time

up to $120 \mathrm{~min}$, drops to a pressure below the initial level. The course of the observed dependence of pressure as a function of time for the samples with collagen can suggest the formation of stable $\mathrm{SiO}_{2}$-Collagen and HAp-Collagen biocomposites.

From the analysis of the course of the temperature curves versus time (Fig. 2), one can see that both for the individual substances $\mathrm{SiO}_{2}$ and $\mathrm{HAp}$ and for the samples with collagen (Fig. 2a, b) the temperature rises to the value of about $33-34{ }^{\circ} \mathrm{C}(200 \mathrm{rpm})$ and $40-42{ }^{\circ} \mathrm{C}(400 \mathrm{rpm})$ and remains constant with the increasing time up to $120 \mathrm{~min}$. Such temperature values ensure the lack of protein denaturation. A small amount of water in the system, physically or structurally adsorbed with the surface of $\mathrm{SiO}_{2}$ or HAP and also contained in the collagen, can in such conditions cause a slight increase in pressure, however, the observed decrease in pressure indicates creation of a stable structure.

Generally, the more intensive changes (of both pressure and temperature) observed when using $400 \mathrm{rpm}$ result from the increased energy created during the collisions of the grinding balls. Structural changes of the $\mathrm{SiO}_{2}$ and Hap, more intensive for $\mathrm{SiO}_{2}$ occur under such conditions (Table 1, Skubiszewska-Zięba et al. 2016). However, it is possible to observe some apparent glass transitions in collagen under these conditions (Del Campo et al. 1963). Such transitions are completely reversible and are observed for collagen which is under stress. Pressure decreasing indicates the system stabilization.

\subsection{Porous structure}

The analysis of shapes of the isotherms (ESM, Figs. S1 and S2) for all studied samples indicates that they have the mesoporous structure. According to the IUPAC classification (Rouquerol et al. 1994), these isotherms are of IV type, and the hysteresis loops can be classified into two types, i.e. $\mathrm{H} 1$ indicating the presence of cylindrical pores and $\mathrm{H} 3$ related to some amount of slit-shape pores. In the range corresponding to the values of high relative pressures $\left(\mathrm{p} / \mathrm{p}_{0}\right)$ the course of the isotherm is quite steep with respect to the pressure axis which indicates a large size of pores of cylindrical shape. The hysteresis loop section below $\mathrm{p} / \mathrm{p}_{0} \approx 0.9$ in a wide range of pressures is horizontal which is due to the presence of slit pores. The pore sizes distribution (PSD) curves (Fig. S1-S4) confirm the mesoporosity of the obtained materials. On the basis of the $\mathrm{PSD}_{\mathrm{BJH}}$ curves for initial $\mathrm{SiO}_{2}$ (Fig. S1a) and HAp (Fig. S2a) it is generally possible to confirm the presence of pores in wide ranges of their sizes from about 3 to $100 \mathrm{~nm}$. The pore size distributions are wide and the maximum indicates that the dominant pores are about $6 \mathrm{~nm}$ $\left(\mathrm{SiO}_{2}\right)$ and $25 \mathrm{~nm}$ (HAp).

As evidenced by the shape of the PSD $_{\mathrm{BJH}}$ curves, the mechanochemical treatment at $400 \mathrm{rpm}$ (Figs. S1b, d and $\mathrm{S} 2 \mathrm{~b}, \mathrm{~d})$ creates pores in a narrower sizes range. The additional peaks of $2-4 \mathrm{~nm}$ diameters are clearly visible on the $\mathrm{dV} / \mathrm{dD}$ curves. This effect is more intensive with the increasing treatment time and also for the samples containing collagen (Figs. S1d and S2d). However, for the samples treated 


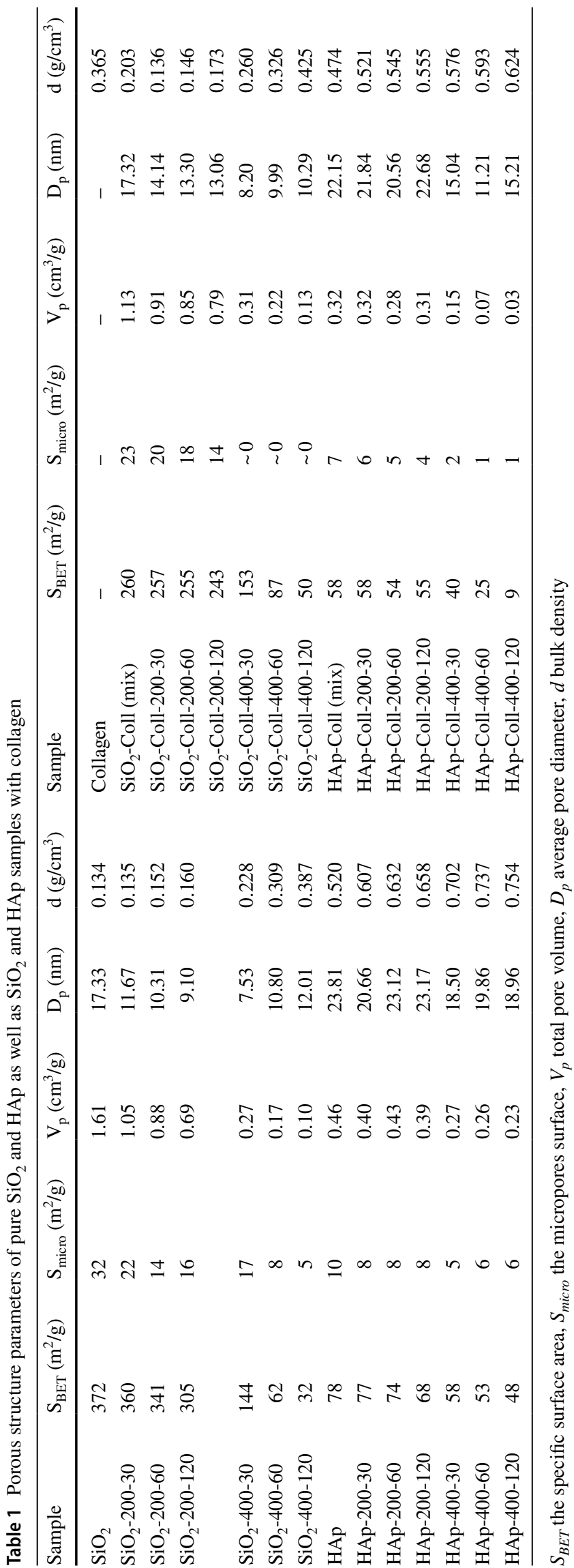

at $200 \mathrm{rpm}$, this effect can be seen only for the HAp samples (Fig. S2a, c). The maxima on the $\mathrm{dV} / \mathrm{dD}$ curves for the pure silica samples with the increasing treatment time shift towards the lower values and thus pores become narrower (Fig. S1a). But for the $\mathrm{SiO}_{2}-$ Collagen systems this effect is less noticeable (Fig. S1c).

Similar conclusions regarding the mesoporous structure of the obtained materials can be drawn by analyzing the PSD curves obtained by the DFT method (Figs. S3, S4). As can seen the composites obtained on the basis of $\mathrm{SiO}_{2}$ (Fig. S3) at $200 \mathrm{rpm}$ are characterize by narrower pores. The maxima on the PSD $_{\mathrm{DFT}}$ curves for these materials are at about 5-6 nm. Milling at $400 \mathrm{rpm}$ causes diminution of the porosity and increase of the size of dominant pores.

The pore sizes distributions of composites prepared on the basis of Hap are slightly different (Fig. S4). The PSD ${ }_{\text {DFT }}$ curves are wide and do not have a clearly developed maximum. Their shape confirms the mesoporous structure of composites.

The analysis of the parameters of porous structure and bulk density (Table 1) shows that both the surface values $\mathrm{S}_{\mathrm{BET}}$ and $\mathrm{S}_{\text {micro }}$ and the pore volume $\mathrm{V}_{\mathrm{p}}$ decrease with the $\mathrm{MChT}$ time. This effect is stronger at higher mill revolutions (400 rpm). However, as expected, the bulk density values (d) increase. The MChT treatment densifies the obtained composites thus forming more mechanically stable systems. It follows from the analysis of $\mathrm{D}_{\mathrm{p}}$ data for the $\mathrm{SiO}_{2}$ samples treated at $400 \mathrm{rpm}$ without collagen and with collagen that, unlike other samples, this parameter increases with the increasing MChT time (from 7.5 to $12 \mathrm{~nm}$, and from 8.2 to $10.3 \mathrm{~nm}$, respectively, Table 1).

The comparison of the changes course of the $\mathrm{S}_{\mathrm{BET}}$ values in relation to the MChT treatment time (Fig. 3) indicates that the $\mathrm{S}_{\mathrm{BET}}$ values for the systems with collagen are lower than those for mechanochemically treated pure $\mathrm{SiO}_{2}$ and Hap (red arrows in Fig. 3). However, for the $\mathrm{SiO}_{2}-$ Collagen systems modified at $400 \mathrm{rpm}$, they have higher $\mathrm{S}_{\mathrm{BET}}$ values compared that for the pure mechanochemically treated $\mathrm{SiO}_{2}$ samples (red arrows in Fig. 3a). Thus it can be assumed that in this case a new spatial structure is formed. However, such relationship is not observed for the HAp-Collagen systems.

\subsection{Thermal analysis}

The TG curves (Fig. 4) corresponding to the $\mathrm{SiO}_{2}$ and $\mathrm{HAp}$ samples in the range to $200{ }^{\circ} \mathrm{C}$ are characterized by a slight weight loss (about $5 \%$ for $\mathrm{SiO}_{2}$ and $1.5 \%$ for $\mathrm{HAp}$ ) associated with the evaporation of physically adsorbed water. A further mass loss up to $1000{ }^{\circ} \mathrm{C}$ is associated with a further slight loss of mass up to about $4 \%$ (for Hap) or the removal of structural water and up to about 6\% (for $\mathrm{SiO}_{2}$ ) it is connected with dehydroxylation of the silica surface. The TG curve for collagen can be divided into three 

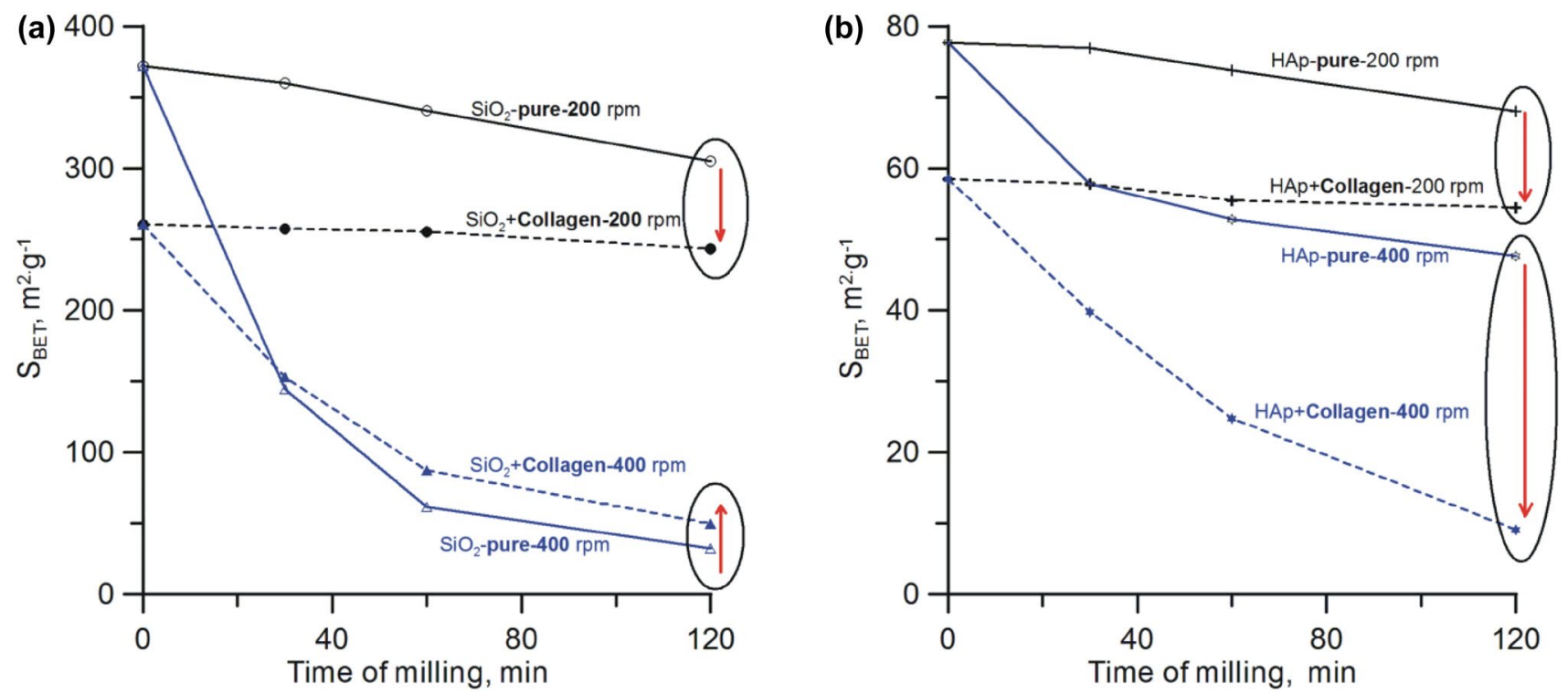

Fig. 3 The course of changes of the specific surface area $\left(\mathrm{S}_{\mathrm{BET}}\right)$ values on the milling time. (Color figure online)

stages in the temperature ranges $20-200{ }^{\circ} \mathrm{C}, 200-400{ }^{\circ} \mathrm{C}$ and $400-800{ }^{\circ} \mathrm{C}$. The first stage up to $200{ }^{\circ} \mathrm{C}$ (about 10\%) is associated with the evaporation of physically adsorbed water, another one up to $400{ }^{\circ} \mathrm{C}$ corresponds probably to the processes of condensation of surface groups in the protein structure with the simultaneous removal of volatile decomposition products. However, the third stage up to $800{ }^{\circ} \mathrm{C}$ is associated with the combustion of organic residue. The exact course of these processes can be also analyzed from the DTG curves (Fig. S5a-c).

Figure 4 shows also the DTA curves of the samples under discussion. For all samples in the temperature range 20-200 ${ }^{\circ} \mathrm{C}$, endothermic peaks associated with the evaporation of physically adsorbed water are visible. For $\mathrm{SiO}_{2}$ and HAp they are also visible in higher temperature ranges. In contrast, for the collagen sample two exothermic peaks in the $200-400{ }^{\circ} \mathrm{C}\left(\mathrm{DTA}_{\max } \approx 300{ }^{\circ} \mathrm{C}\right)$ and $400-800{ }^{\circ} \mathrm{C}$ $\left(\mathrm{DTA}_{\max } \approx 580^{\circ} \mathrm{C}\right.$ ) ranges associated with condensation and combustion processes correspondingly are observed.

The TG curves obtained for the composites (Fig. 5a) resemble that for pure collagen (Fig. 4), however, the final decomposition step for the series of $\mathrm{SiO}_{2}$-Collagen samples mechanochemically treated at $200 \mathrm{rpm}$ (Fig. 5a) ends already at $600{ }^{\circ} \mathrm{C}$. This may indicate a homogeneous distribution of thin collagen layers on the silica surface causing better access of air during heating and, as a result, faster burning. This is also reflected in the shape of DTA curves registered for the composites (Fig. 5a) in comparison to the collagen DTA curve (Fig. 4). It can be seen that the first peak DTA for the composites is higher and the second one is lower whereas for collagen it is opposite. In addition, the descending DTA branch for the composites is corrugated.

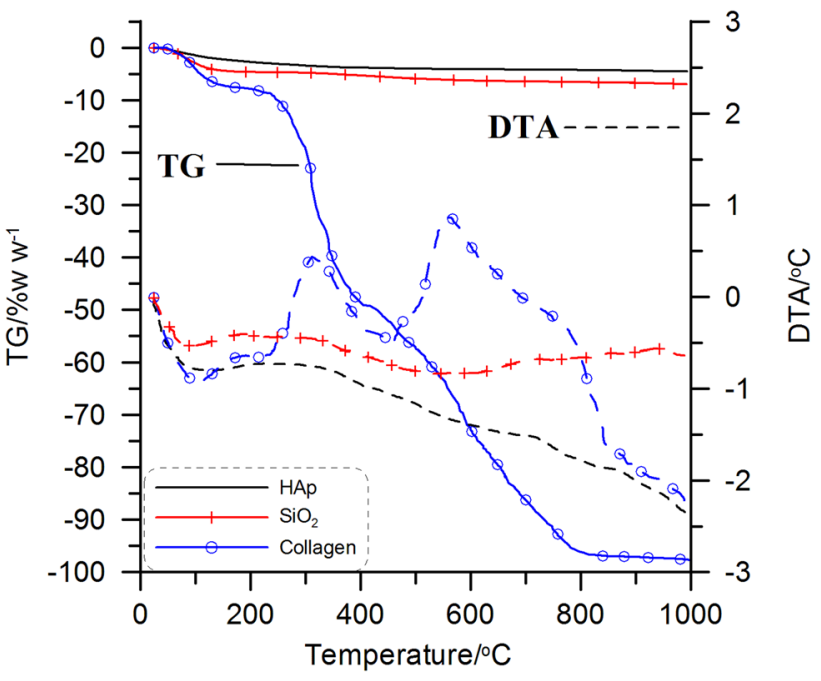

Fig. 4 The TG and DTA curves for the individual substances, i.e. collagen, silica and hydroxyapatite used for preparation of biocomposite samples

The discussed differences are more pronounced in the case of a series of $\mathrm{SiO}_{2}-$ Collagen composites treated at $400 \mathrm{rpm}$ (Fig. 5b). For this series of samples, combustion already ends at about $550^{\circ} \mathrm{C}$ and peaks on the DTA curves (Fig. 5b) are higher and narrower.

For the series of HAp-Collagen composites processed at $200 \mathrm{rpm}$ (Fig. 6a), the combustion stage ends at about $580^{\circ} \mathrm{C}$, and for those mechanochemically treated at $400 \mathrm{rpm}$ (Fig. 6b) this process ends already at $500{ }^{\circ} \mathrm{C}$. Most likely, greater affinity of hydroxyapatite for to collagen results in a better distribution of protein in the mineral matrix. This is 

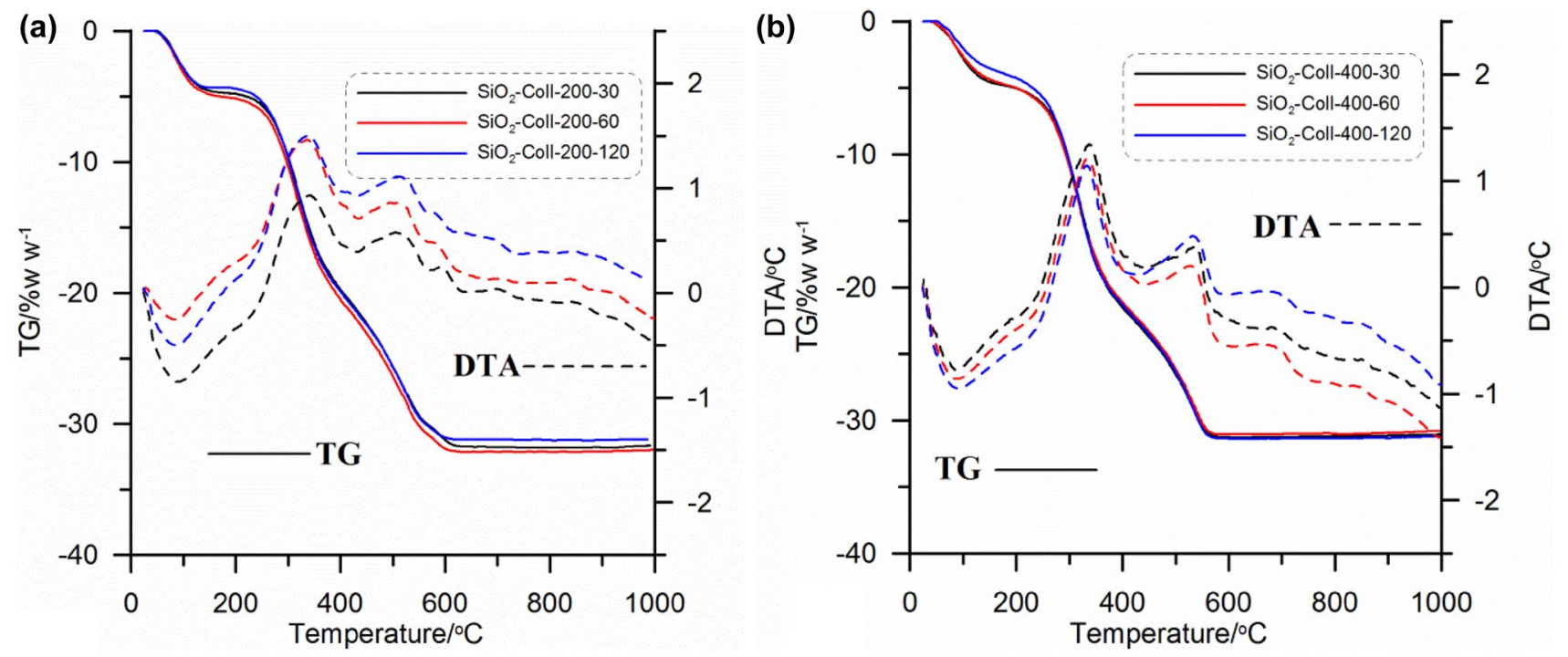

Fig. 5 The TG and DTA curves for the $\mathrm{SiO}_{2}$-Collagen biocomposites milled at $200 \mathrm{rpm}$ (a) and $400 \mathrm{rpm}$ (b)
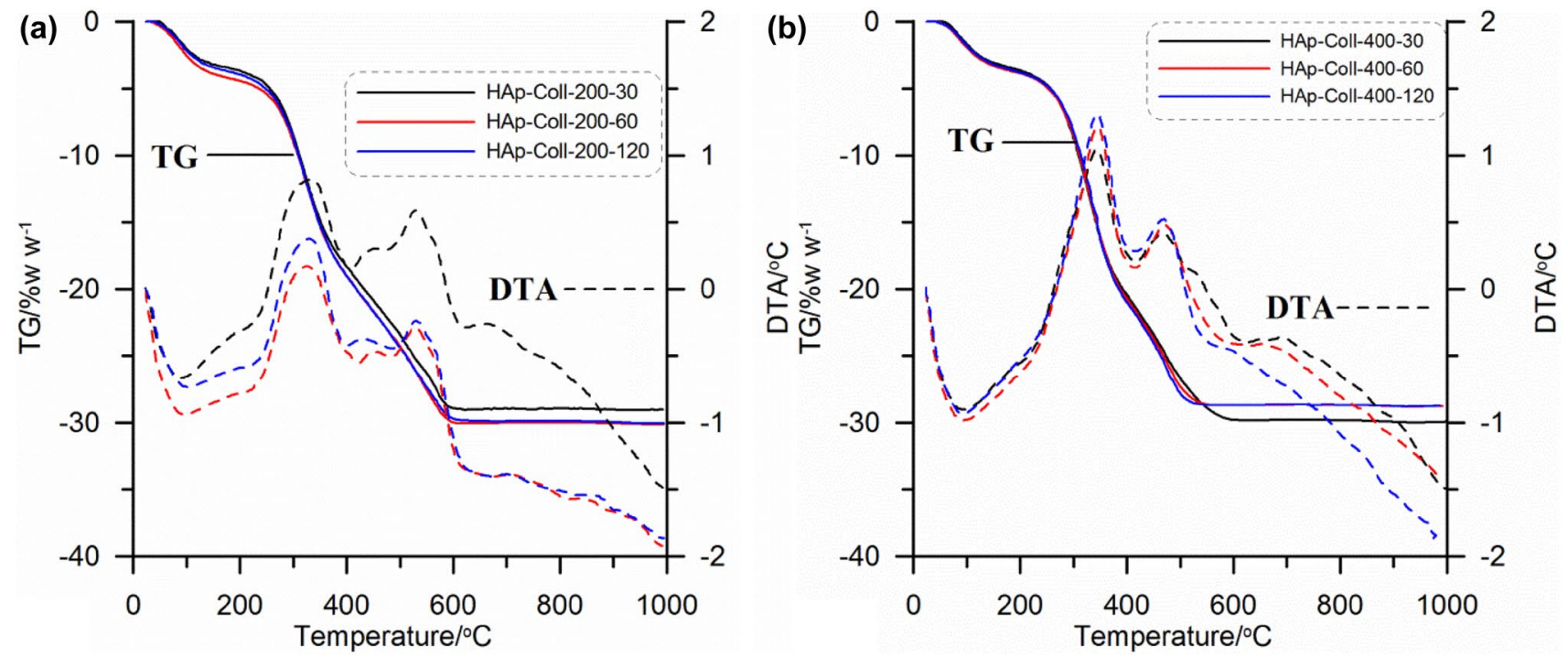

Fig. 6 The TG and DTA curves for the HAp-Collagen biocomposites milled at $200 \mathrm{rpm}$ (a) and $400 \mathrm{rpm}$ (b)

also reflected in the shape of DTA curves for the corresponding HAp-Collagen composites (Fig. 6a, b). The higher the mill revolutions, the narrower DTA peaks. The influence of the rotation speed on the thermal stability of materials is clearly visible on the DTG curves for the materials obtained on the basis of Hap (Fig. S2c).

The SEM analysis of the initial HAp (Fig. S6) indicates the spongy structure of material. One can see the big intergranular spaces between the crystals of similar longitudinal structure which suggests low density and a relatively high pores volume. Mechanochemical milling with collagen at 200 and 400 rpm causes (Fig. S7a, b) that materials are more compact and intergranular spaces become smaller. The rotation speed $200 \mathrm{rpm}$ is less effective. On the basis of SEM images one can predict greater density and smaller porosity of composites compared to the initial Hap. This is consistent with the data included in Table 1.

\section{Conclusions}

During the MChT processes of pure $\mathrm{SiO}_{2}$ and $\mathrm{HAp}$ at $200 \mathrm{rpm}$ the created pressure builds up initially and in a longer period of time it remains almost constant. However, 
for the composites with collagen at both 200 and $400 \mathrm{rpm}$, the pressure increases initially and next decreases with the increasing time. This can prove formation of material of a stable structure.

At the rotations of $200 \mathrm{rpm}$ during MChT, the values of specific surface area $\left(\mathrm{S}_{\mathrm{BET}}\right)$ and pore volume $\left(\mathrm{V}_{\mathrm{p}}\right)$ decrease for both the individual substances $\left(\mathrm{HAp}\right.$ and $\left.\mathrm{SiO}_{2}\right)$ and their composites with collagen. However, at $400 \mathrm{rpm}$ the $\mathrm{SiO}_{2}-$ Collagen composites have higher $\mathrm{S}_{\mathrm{BET}}$ and $\mathrm{V}_{\mathrm{p}}$ values than $\mathrm{SiO}_{2}$ mechanochemically treated in pure state. Based on this it can be assumed that under such conditions a new spatial structure of composite is created. The structural changes caused by MChT are also visible on SEM images.

The collagen degradation temperature in the mineral-collagen composites is lower and its range is narrower compared to that for pure collagen. This can be the proof of good connection of both mineral and protein components in the prepared $\mathrm{SiO}_{2}-$ Collagen and $\mathrm{HAp}-$ Collagen biocomposites.

Acknowledgements The research was partly carried out under the Agreement between the Government of the Republic of Poland and the Government of Ukraine on cooperation in the field of science and technology signed in Kiev on January 12, 1993 (Grant Agreement No. M/118-2018).

Open Access This article is distributed under the terms of the Creative Commons Attribution 4.0 International License (http://creativeco mmons.org/licenses/by/4.0/), which permits unrestricted use, distribution, and reproduction in any medium, provided you give appropriate credit to the original author(s) and the source, provide a link to the Creative Commons license, and indicate if changes were made.

\section{References}

Aryal, S., Bhattarai, S.R., Bahadur, R.K.C., Khil, M.S., Lee, D.-R., Kim, H.Y.: Carbon nanotubes assisted biomimetic synthesis of hydroxyapatite from simulated body fluid. Mater. Sci. Eng. A 426(1-2), 202-207 (2006). https://doi.org/10.1016/j. msea.2006.04.004

Baláž, P.: Mechanochemistry in Nanoscience and Minerals Engineering. Springer, Berlin (2008). http://www.springer.com/978-3-54074854-0

Baláž, P., Achimovičová, M., Balaž, M., Billik, P., Cherkezova-Zheleva, Z., Criado, J.M., Delogu, F., Dutková, E., Gaffet, E., Gotor, F.J., Kumar, R., Mitov, I., Rojac, T., Senna, M., Streletskii, A., Wieczorek-Ciurowa, K.: Hallmarks of mechanochemistry: from nanoparticles to technology. Chem. Soc. Rev. 42, 7571-7637 (2013). https://doi.org/10.1039/c3cs35468g

Barret, E.P., Joyner, L.G., Halenda, P.P.: The determination of pore volumes and area distributions in porous substances. J. Am. Chem. Soc. 73, 373-375 (1951)

Bella, J., Brodsky, B., Berman, H.M.: Hydration structure of a collagen peptide. Structure. 3(9), 893-906 (1995). https://doi.org/10.1016/ S0969-2126(01)00224-6

Boldyrev, V.V.: Mechanochemistry and mechanical activation of solids. Russ. Chem. Rev. 75(3), 179-189 (2006). https://doi.org/10.1070/ RC2006v075n03ABEH001205
Boldyrev, V.V., Tkacova, K.: Mechanochemistry of solids: past, present and prospects. J. Mater. Synth. Process. 8(3-4), 121-132 (2000) 02000

Butyagin, P.Y.: Kinetics and nature of mechanochemical reactions. Russ. Chem. Rev. 40, 901-915 (1971)

Chaikina, M.V., Bulina, N.V., Ishchenko, A.V., Prosanov, I.Yu.: Mechanochemical synthesis of hydroxyapatite and its modifications: composition, structure, and properties. Russ. Phys. J. 56(10), 1176-1182 (2014). https://doi.org/10.1007/s11182-014-0159-0

Del Campo, F.F., Paneque, A., Ramirez, J.M., Losada, M.: Thermal transitions in collagen. Biochim. Biophys. Acta 66, 448-452 (1963). https://doi.org/10.1016/0006-3002(63)91215-0)

Dorner-Reisel, A., Berroth, K., Neubauer, R., Nestler, K., Marx, G., Scislo, M., Müller, E., Slosarcyk, A.: Unreinforced and carbon fibre reinforced hydroxyapatite: resistance against microabrasion. J. Eur. Ceram. Soc. 24(7), 2131-2139 (2004). https://doi. org/10.1016/S0955-2219(03)00373-X

Evans, R., Marconi, U.M.B., Tarazona, P.: Capillary condensation and adsorption in cylindrical and slit-like pores. J. Chem. Soc. Faraday Trans. II 82, 1763-1787 (1986). https://doi.org/10.1039/F2986 8201763

Fahami, A., Ebrahimi-Kahrizsangi, R., Nasiri-Tabrizi, B.: Mechanochemical synthesis of hydroxyapatite/titanium nanocomposite. Solid State Sci. 13, 135-141 (2011). https://doi.org/10.1016/j. solidstatesciences.2010.10.026

Gregg, S.J., Sing, K.S.W.: Adsorption, Surface Area and Porosity, 2nd edn. Academic Press, London (1982)

Harrison, B.S., Atala, A.: Carbon nanotube applications for tissue engineering. Biomaterials. 28(2), 344-353 (2007). https://doi. org/10.1016/j.biomaterials.2006.07.044

Hulmes, D.J.S.: Collagen diversity, synthesis and assembly. In: Fratzl, P. (ed.) Collagen. Springer, Boston (2008). http://www.springer. com/978-0-387-73905-2

Joschek, S., Nies, B., Krotz, R.: Chemical and physicochemical characterization of porous hydroxyapatite ceramics made of natural bone. Biomaterials. 21(16), 1645-1658 (2000). https://doi. org/10.1016/S0142-9612(00)00036-3

Landers, J., Yu, G., Neimark, A.: Density functional theory methods for characterization of porous materials. Colloids Surf. A 437, 3-32 (2013). https://doi.org/10.1016/j.colsurfa.2013.01.007

Liu, J., Ye, X., Wang, H., Zhu, M., Wang, B., Yan, H.: The influence of $\mathrm{pH}$ and temperature on the morphology of hydroxyapatite synthesized by hydrothermal method. Ceram. Int. 29, 629-633 (2003). https://doi.org/10.1016/S0272-8842(02)00210-9

Mochales, C., El, B., Abdeslam, H., Ginebra, M.P., Terol, A., Planell, J.A., Boudeville, P.: Dry mechanochemical synthesis of hydroxyapatites from DCPD and $\mathrm{CaO}$ : influence of instrumental parameters on the reaction kinetics. Biomaterials. 25, 1151-1158 (2004). https://doi.org/10.1016/j.biomaterials.2003.08.002

Pal, A., Maity, S., Chabri, S., Bera, S., Chowdhury, A.R., Das, M., Sinha, A.: Mechanochemical synthesis of nanocrystalline hydroxyapatite from Mercenaria clam shells and phosphoric acid. Biomed. Phys. Eng. Express. 3(1), 015010 (2017). https://doi. org/10.1088/2057-1976/aa54f5

Parenteau-Bareil, R., Gauvin, R., Berthod, F.: Collagen-based biomaterials for tissue engineering applications. Materials. 3(3), 1863-1887 (2010). https://doi.org/10.3390/ma3031863

Rouquerol, J., Baron, G., Denoyel, R., Giesche, H., Groen, J., Klobes, P., Levitz, P., Neimark, A.V., Rigby, S., Skudas, R., Sing, K., Thommes, M., Unger, K.: Recommendations for the characterization of porous solids. Pure Appl. Chem. 66(8), 1739-1758 (1994). https://doi.org/10.1351/pac199466081739

Sepelak, V., Becker, K.: Mechanochemistry: from mechanical degradation to novel materials properties. J. Korean Ceram. Soc. 49(1), 19-28 (2012). https://doi.org/10.4191/kcers.2012.49.1.019 
Sionkowska, A., Kozłowska, J.: Characterization of collagen/ hydroxyapatite composite sponges as a potential bone substitute. Int J Biol Macromol. 47, 483-487 (2010). https://doi. org/10.1016/j.ijbiomac.2010.07.002

Skubiszewska-Zięba, J.: Green chemistry in preparation of adsorbents and catalysts. In: Filipović, L.A. (ed.) Milling: Operations, Applications and Industrial Effects. Nova Science Publishers Inc., New York (2011)

Skubiszewska-Zięba, J., Khalameida, S., Sydorchuk, V.: Comparison of surface properties of silica xero- and hydrogels hydrothermally modified using mechanochemical, microwave and classical methods. Colloids Surf. A. 504, 139-153 (2016). https://doi. org/10.1016/j.colsurfa.2016.05.066

Skwarek, E., Janusz, W., Sternik, D.: Adsorption of citrate ions on hydroxyapatite synthetized by various methods. J. Radioanal. Nucl. Chem. 299, 2027-2036 (2014). https://doi.org/10.1007/ s10967-013-2825-z

Sobczak, A., Kowalski, Z.: Hydroxyapatite materials applied in implantology. Czasopismo Techniczne 104, 149-158 (2007). http://suw. biblos.pk.edu.pl/resourceDetails\&rId=831 (in Polish)

Swetha, M., Sahithi, K., Moorthi, A., Srinivasan, N., Ramasamy, K., Selvamurugan, N.: Biocomposites containing natural polymers and hydroxyapatite for bone tissue engineering. Int. J. Biol. Macromol. 47(1), 1-4 (2010). https://doi.org/10.1016/j.ijbio mac.2010.03.015

Takacs, L.: What is unique about mechanochemical reactions? Acta Phys. Pol. A 126, 1040-1043 (2014). https://doi.org/10.12693/ APhysPolA.126.1040
Venugopal, J., Low, S., Aw, T., Kumar, T.S., Ramakrishna, S.: Mineralization of osteoblasts with electrospun collagen/hydroxyapatite nanofibers. J. Mater. Sci. Mater. Med. 19(5), 2039-2046 (2008). https://doi.org/10.1007/s10856-007-3289-x

Wahl, D.A., Czernuszka, J.T.: Collagen-hydroxyapatite composites for hard tissue repair. Eur. Cell Mater. 11, 43-56 (2006). https://doi. org/10.22203/eCM.v011a06

Yeong, K.C.B., Wang, J., Ng, S.C.: Mechanochemical synthesis of nanocrystalline hydroxyapatite from $\mathrm{CaO}$ and $\mathrm{CaHPO} 4$. Biomaterials. 22(21), 2705-2712 (2001). https://doi.org/10.1016/S0142 $-9612(00) 00257-\mathrm{X}$

Yoshikawa, H., Tamai, N., Murase, T., Myoui, A.: Interconnected porous hydroxyapatite ceramics for bone tissue engineering. J. R. Soc. Interface 6(3), 341-348 (2008). https://doi.org/10.1098/ rsif.2008.0425.focus

Zhou, H., Lee, J.: Nanoscale hydroxyapatite particles for bone tissue engineering. Acta Biomater. 7(7), 2769-2781 (2011). https://doi. org/10.1016/j.actbio.2011.03.019

Publisher's Note Springer Nature remains neutral with regard to jurisdictional claims in published maps and institutional affiliations. 